\title{
Input Quantity and Distribution of Hexachlorocyclohexane (HCH) in the Jiaozhou Bay Waters
}

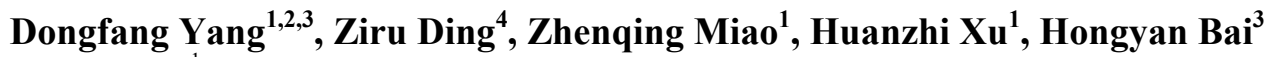 \\ ${ }^{1}$ Marine Science College, Zhejiang Ocean University, Zhoushan, China \\ ${ }^{2}$ North China Sea Environmental Monitoring Center, State Oceanic Administration (SOA), Qingdao, China \\ ${ }^{3}$ College of Life Science, Shanghai Ocean University, Shanghai, China \\ ${ }^{4}$ The Fourth Branch, China Ocean Monitoring, State Oceanic Administration (SOA), Ningbo, China \\ Email: dfyang@shou.edu.cn
}

Received January 2, 2012; revised February 2, 2012; accepted March 1, 2012

\begin{abstract}
Based on data from the investigation in Jiaozhou bay waters in May, July and November in 1987, the distribution, source and seasonal variation of HCH in Jiaozhou Bay are analyzed. The results showed that in Jiaozhou bay HCH content was very low and less than $0.100 \mu \mathrm{g} / \mathrm{L}$ in this year, and better than the national Category I of the sea water quality standard, and the water quality about $\mathrm{HCH}$ was very clean; and that The seasonal variation of the $\mathrm{HCH}$ content in Jiaozhou bay waters has already vanished, namely, the seasonal variation of the HCH content in this year was not influenced by the rainfall, the runoffs or rivers. The horizontal distributions of the $\mathrm{HCH}$ content in the whole bay waters showed that the $\mathrm{HCH}$ content in the bay was not only directly input from both runoffs but also from rivers, the $\mathrm{HCH}$ source was area-source and came from land. The vertical distributions of the HCH content in the whole bay waters showed that the change of the $\mathrm{HCH}$ content at surface was not consistent with the corresponding one at bottom, and that the trend of the $\mathrm{HCH}$ distribution at surface was not consistent with that at bottom, and that only the $\mathrm{HCH}$ contents at surface and bottom were very close. From the year of four years ago of the prohibition (1979), to the prohibition year of $\mathrm{HCH}$ use (1983), and finally to the year after the four years of the prohibition (1987), The change of the HCH input into the bay waters unveiled that the by four years before the prohibition, the pollution of the HCH on land was very grave, and by four years after the prohibition, the $\mathrm{HCH}$ content in waters was very low, whose process represented that the process of human being having broken up the earth and the process of the earth having naturally restored. Therefore, Human being would consider not only for own benefits but also for the sustainable development of environment.
\end{abstract}

Keywords: HCH; Distribution; Prohibition; Input Quantity; Jiaozhou Bay

\section{Introduction}

In China, a large amount of $\mathrm{HCH}$ has ever been produced and used. Since 1950, Having tested and produced $\mathrm{HCH}$ played an important role in the prevention and cure of migratory locust, taking major contribution to agricultural production and injurious insect prevention. However, as $\mathrm{HCH}$ has high toxicity and is difficult to decompose as well as to harm in large area, its use was prohibited in our country in 1983. Although after the prohibition the residual quantity in soil and water body obviously reduced, it still also could examine the certain concentration $\mathrm{HCH}$ [1-14]. Then, this serious research on the distribution and content of $\mathrm{HCH}$ in water area would make it clear to which degree that human being destroys

*Funded by Key Laboratory of Marine Spill Oil Identification and Damage Assessment Technology, SOA, the Director's Foundation of the Beihai Monitoring Center, the State Oceanic Administration; and a Project of Chinese Academy of Science (KZCX 2-207). environment through $\mathrm{HCH}$ before and after the prohibition, and how the nature would eliminate $\mathrm{HCH}$ in environment through the land and waters transfer process [1-14].

In this paper, according to the data from the investigation in Jiaozhou bay waters in May, July and November in 1987, the source, distribution and transfer of $\mathrm{HCH}$ in the marine area of Jiaozhou bay after 4 years of the prohibition would be analyzed, studying the change of HCH's input quantity in 1979, 1983 (the year of $\mathrm{HCH}$ prohibition) and 1987 provided the theoretical proofs for the research on the states of the earth polluted through $\mathrm{HCH}$ by human being and $\mathrm{HCH}$ in nature eliminated by the earth.

\section{Material and Method}

Jiaozhou Bay is a semi-closed natural inland bay, located in the central of Yellow Sea, south of Shandong Penin- 
sula, between longitude $120^{\circ} 04^{\prime}-23^{\prime}$ and latitude $35^{\circ} 58^{\prime}$ $36^{\circ} 18^{\prime}$, its depth is shallow (average depth of $7 \mathrm{~m}$ ), the bay mouth is narrow (about $2.5 \mathrm{~km}$ ), and the time of completing the seawater exchange in the Jiaozhou bay is about 15 days [4-6]. In the eastern and northeastern coast of the Jiaozhou bay there is the Qingdao's industrialintensive area. There are some main rivers such as Yang river and Dagu river into the Jiaozhou bay. In the east of the bay, Haibo, Licun and Lou rivers with a lot of industrial and domestic waste water into the bay brings a lot of pollutant, causing the damage of the bay environment.

The data used here were recorded in May, July and November in 1987 by the North China Sea Environmental Monitoring Center, SOA, in six stations: 31, 32, 33, 34, 35 and 47 (Figure 1). Water samples were collected according to the depth of water (if more than $15 \mathrm{~m}$, collect surface layer and bottom layer; if less than $15 \mathrm{~m}$, only collect surface layer). In the investigation and sampling, on-site the seawater samples were filtrated, kept in polyethylene flask in cold storage and mensurated in lab by gas chromatography, with which Tangxiu Gu's method [4] was consistant.

\section{Results}

\subsection{Amount of Content}

In the whole Jiaozhou bay waters area, the $\mathrm{HCH}$ content was very low in May, July and November, its content range was $0.0121-0.0901 \mu \mathrm{g} / \mathrm{L}$, which showed that in May, July and November in the surface waters in the whole Jiaozhou bay, the seawater quality in $\mathrm{HCH}$ reached Category I $(1.00 \mu \mathrm{g} / \mathrm{L})$ of the National Standard of China for Seawater Quality GB3097-1997 (in which 3 categories 1 to 3 are classified from the best to the worst). The $\mathrm{HCH}$ content was lower than $0.100 \mu \mathrm{g} / \mathrm{L}$ in the whole Jiaozhou waters area, indicating that on aspect of HCH's content, the seawater quality was so clean in the whole Jiaozhou bay (Table 1).

\subsection{Horizontal Distribution}

In May and November, in Jiaozhou bay waters, the horizontal distribution of $\mathrm{HCH}$ in the surface water area showed that the isoline on the $\mathrm{HCH}$ content (Figures 2-3) parallelled northeastern coastline and formed a series of parallels with different grades. Its content decreased from northern off-shore to southern bay mouth. In May, it decreased from $0.0901 \mu \mathrm{g} / \mathrm{L}$ to $0.0144 \mu \mathrm{g} / \mathrm{L}$ (Figure 2); in November, it decreased from $0.0821 \mu \mathrm{g} / \mathrm{L}$ to $0.0291 \mu \mathrm{g} / \mathrm{L}$ (Figure 3). In July, in Jiaozhou bay waters, the horizontal distribution of $\mathrm{HCH}$ in the surface water area showed that the isoline on the $\mathrm{HCH}$ content (Figure 4) represented in the surface water off the shore between estuaries of Haibo River and Lichun River there was relatively high content area and formed a high content center with a series of different grades, decreasing from $0.0213 \mu \mathrm{g} / \mathrm{L}$ in

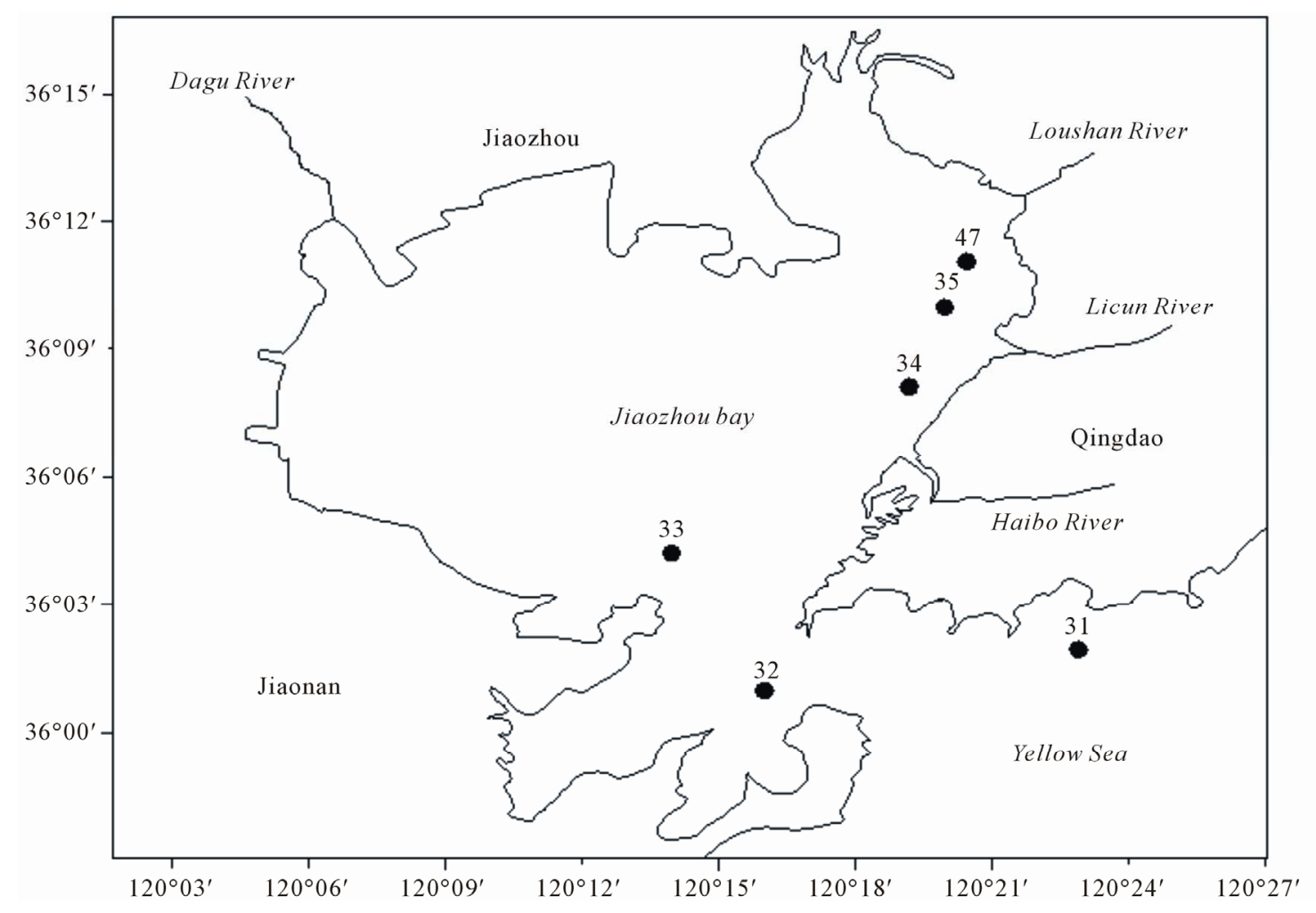

Figure 1. Investigation sites in Jiaozhou Bay. 
Table 1. The surface water quality in Jiaozhou bay in May, July and November.

\begin{tabular}{cccc}
\hline Time & May & July & November \\
\hline HCH content in seawater $(\mu \mathrm{g} / \mathrm{L})$ & $0.0144-0.0901$ & $0.0121-0.0213$ & $0.0291-0.0821$ \\
The National Standard of China for Seawater Quality & Category I & Category I & Category I \\
\hline
\end{tabular}

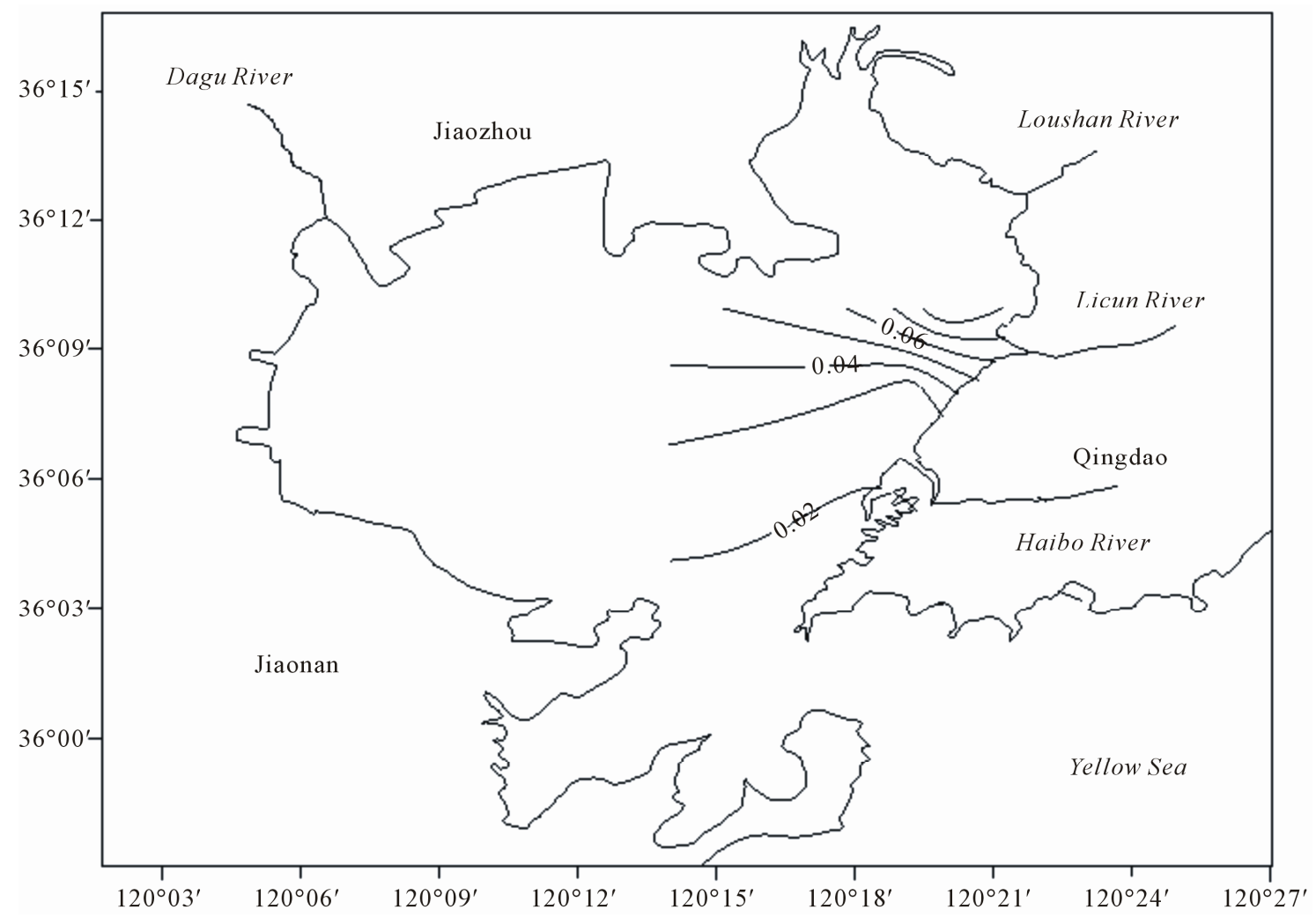

Figure 2. HCH content distribution in surface in Jiaozhou Bay in May $(\mu \mathrm{g} / \mathrm{L})$.

the center outwards to $0.0121 \mu \mathrm{g} / \mathrm{L}$. Obviously, in Jiaozhou bay waters, $\mathrm{HCH}$ content was very low, and forming the center with the $\mathrm{HCH}$ high content is mainly influenced by the slight disturbance of river.

In May, July and November, in the bottom water area of Jiaozhou bay mouth, the HCH's horizontal distribution showed that the isoline of the $\mathrm{HCH}$ content at bottom (Figures 5-7), which almost paralleled with the line connedting both side shores of the bay mouth and formed parallel lines with a series of different grades.

In the Jiaozhou bay mouth waters, being divided into the inner bay mouth waters, the bay mouth waters, the outer bay mouth waters, in May, July and November,the $\mathrm{HCH}$ content at bottom decreased from the bay mouth to the inner or outer bay mouth. In May, it decreased from $0.0186 \mu \mathrm{g} / \mathrm{L}$ to $0.0137 \mu \mathrm{g} / \mathrm{L}$ (Figure 5). In July, it decreased from $0.0131 \mu \mathrm{g} / \mathrm{L}$ to $0.0118 \mu \mathrm{g} / \mathrm{L}$ (Figure 6); in November, it decreased from $0.0296 \mu \mathrm{g} / \mathrm{L}$ to $0.0242 \mu \mathrm{g} / \mathrm{L}$ (Figure 7).
In May, July and November, in the bay mouth waters, the $\mathrm{HCH}$ content range at bottom is $0.0118-0.0296$ $\mu \mathrm{g} / \mathrm{L}$.

\subsection{Vertical Distribution}

There was three stations 31,32 and 33 in the bay mouth waters, among which station 33 was the inner bay mouth and station 31 the outer. In May, the $\mathrm{HCH}$ content in surface was higher than that in the corresponding bottom. The absolute gap of the $\mathrm{HCH}$ content between the surface and bottom is $0.0007-0.0026 \mu \mathrm{g} / \mathrm{L}$. In July, from the inner bay mouth, to the bay mouth, to the outer bay mouth, the $\mathrm{HCH}$ content in surface changed from higher than it in the corresponding bottom to lower than it in the corresponding bottom. The absolute gap of $\mathrm{HCH}$ content between in surface and bottom is $0.0002-0.0095 \mu \mathrm{g} / \mathrm{L}$. In November, from the inner bay mouth, to the bay mouth, to the outer bay mouth, the $\mathrm{HCH}$ content in sur face changed from higher than it in the corresponding 


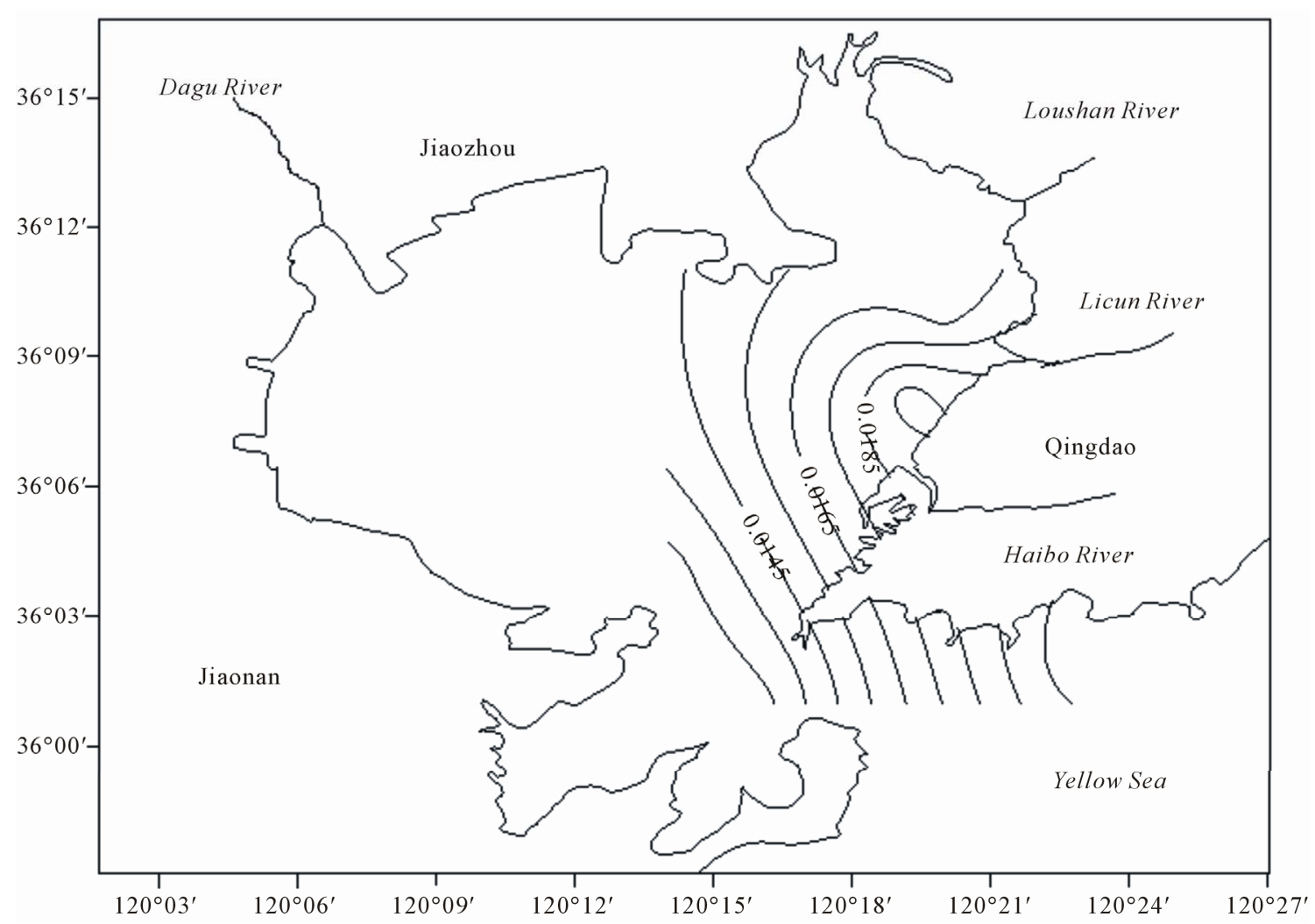

Figure 3. HCH content distribution in surface in Jiaozhou Bay in July $(\mu \mathrm{g} / \mathrm{L})$.

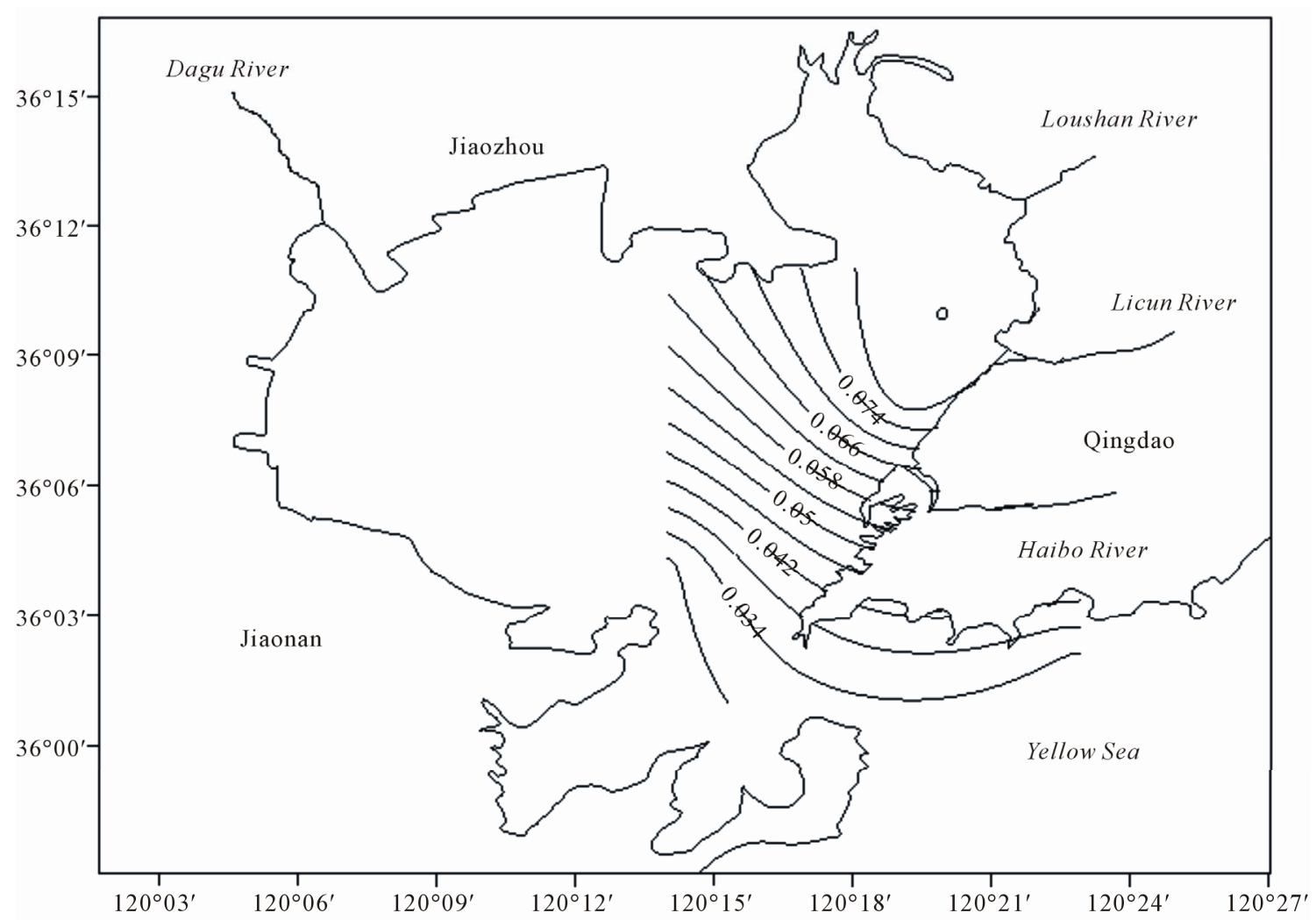

Figure 4. HCH content distribution in surface in Jiaozhou Bay in November $(\mu \mathrm{g} / \mathrm{L})$. 


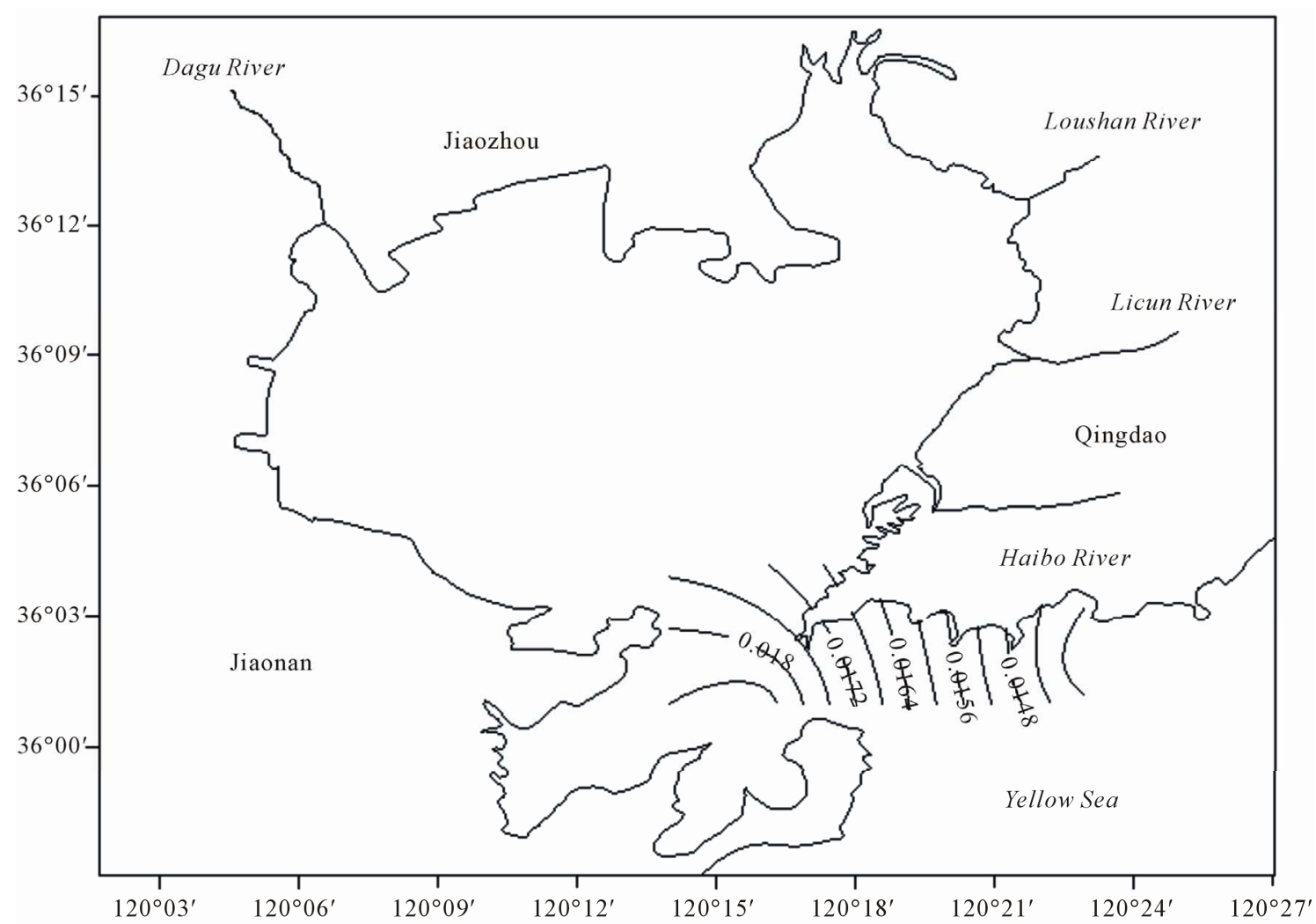

Figure 5. HCH content distribution in bottom in Jiaozhou Bay in May ( $\mu \mathrm{g} / \mathrm{L})$.

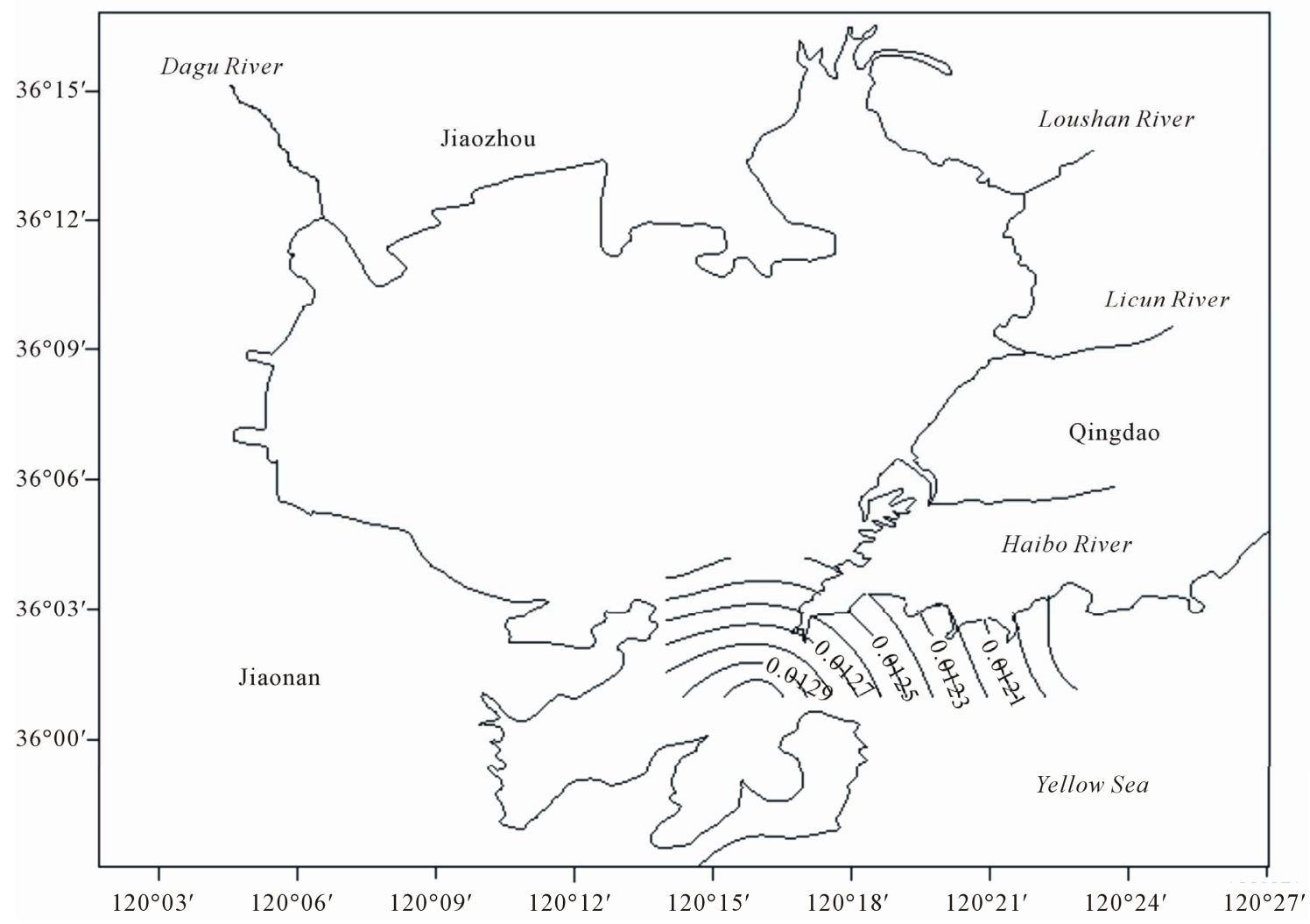

Figure 6. HCH content distribution in bottom in Jiaozhou Bay in July $(\mu \mathrm{g} / \mathrm{L})$. 


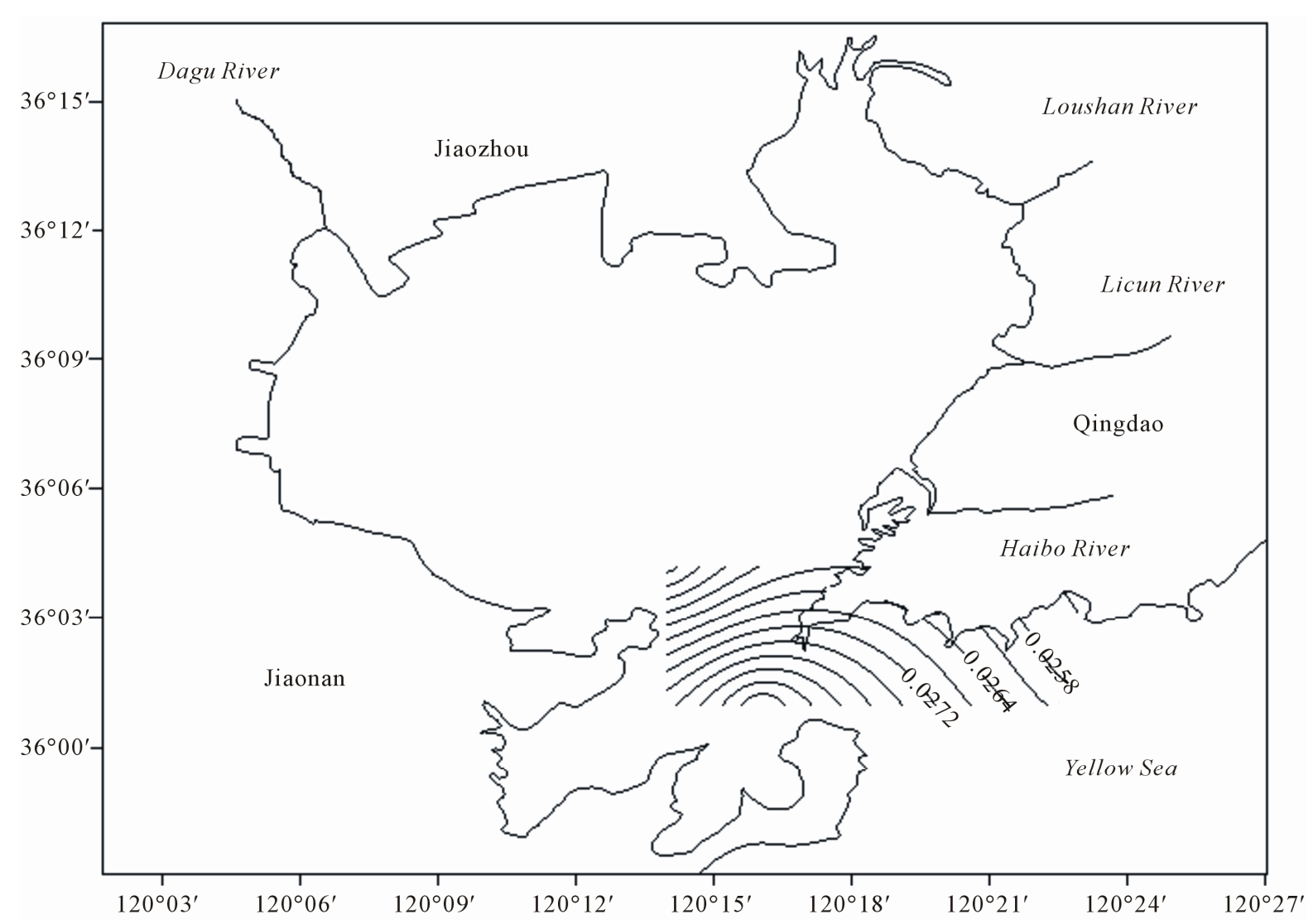

Figure 7. HCH content distribution in bottom in Jiaozhou Bay in November ( $\mu \mathrm{g} / \mathrm{L})$.

bottom to lower than it in the corresponding bottom. The absolute gap of $\mathrm{HCH}$ content between in surface and bottom is $0.0019-0.0074 \mu \mathrm{g} / \mathrm{L}$.

The $\mathrm{HCH}$ content in the horizontal distribution of $\mathrm{HCH}$ in surface decreased from the inner bay mouth to the bay mouth, to the outer bay mouth. However, it in the horizontal distribution of $\mathrm{HCH}$ in bottom decreased from the bay mouth to the inner bay mouth or to the outer. The $\mathrm{HCH}$ horizontal distribution and variable trend between in the surface and bottom were inconsistent.

Therefore, in May, July and November, in the bay mouth waters, the $\mathrm{HCH}$ contents between in surface and bottom were close. However, The $\mathrm{HCH}$ horizontal distribution and variable trend between in the surface and bottom were inconsistent.

\subsection{Seasonal Distribution}

In Jiaozhou bay waters, in May, the $\mathrm{HCH}$ content in surface was $0.0144-0.0901 \mu \mathrm{g} / \mathrm{L}$; in July, it was 0.0121 $0.0213 \mu \mathrm{g} / \mathrm{L}$; in November, it was $0.0291-0.0821 \mu \mathrm{g} / \mathrm{L}$. The variable range of the $\mathrm{HCH}$ content in May included the one-year variable one. Therefore, in May, July and November, the $\mathrm{HCH}$ content range in surface was very close. There was no seasonal distribution of $\mathrm{HCH}$ in water area.

\section{Discussion}

\subsection{Water Quality}

In the whole Jiaozhou bay waters, the $\mathrm{HCH}$ content was very low, $0.0121-0.0901 \mu \mathrm{g} / \mathrm{L}$, in May, July and November. The $\mathrm{HCH}$ content in the whole bay waters not only reached Category I $(1.00 \mu \mathrm{g} / \mathrm{L})$ but also was lower than $1.00 \mu \mathrm{g} / \mathrm{L}$, whose seawater quality in $\mathrm{HCH}$ was the same as that in 1985 [10] and in 1986 [11], being better than Category I $(1.00 \mu \mathrm{g} / \mathrm{L})$. In the whole Jiaozhou bay waters, the seawater quality was very clean in $\mathrm{HCH}$. With the $\mathrm{HCH}$ content becoming very low, much lower than $1.00 \mu \mathrm{g} / \mathrm{L}$, and by the action of sea possessing uniformity [10], the $\mathrm{HCH}$ content in surface in waters have already been no seasonal variation. Therefore, in May, July and November, the $\mathrm{HCH}$ content range in surface in waters body is very close, now there was no seasonal distribution of $\mathrm{HCH}$ in waters body.

\subsection{Source}

In May and November, in Jiaozhou bay waters, the isoline of the $\mathrm{HCH}$ content in surface (Figures 2-3) paralleled the northeastern coastline and formed a series of parallel lines with different grades. The $\mathrm{HCH}$ content in surface decreased from the off-shore in north to the bay 
mouth, which was consistent with the change of $\mathrm{HCH}$ content in 1983, 1984, 1985 and 1986 [8-11]. Therefore, $\mathrm{HCH}$ directly is inputted into the off shore waters area through runoff so its content was very low.

In July, in Jiaozhou bay waters, in the horizontal distribution of $\mathrm{HCH}$ in surface, the isoline of the $\mathrm{HCH}$ content in surface (Figure 4) formed a series of semi-circle with different grades in eastern off-shore, its content decreased from the eastern off-shore to outward. It was evident that as $\mathrm{HCH}$ content in surface waters was very low, by the slight disturbance of the river input into the bay waters, the horizontal distribution of the $\mathrm{HCH}$ content showed the obvious change. So, $\mathrm{HCH}$ was input by the river into the coastal waters, and its content was very low.

In 1983, China began to take the $\mathrm{HCH}$ prohibition. The HCH content in Jiaozhou bay waters was only from the $\mathrm{HCH}$ remnant in soil. Then, the $\mathrm{HCH}$ content input by the rivers into the off-shore waters was the same as directly by runoff on the earth's surface, which was very low, lower than $0.100 \mu \mathrm{g} / \mathrm{L}$, expressing that the $\mathrm{HCH}$ remnant on land decreased largely [9].

\subsection{Land Transfere}

In Jiaozhou bay coastal waters, the HCH content in surface decreased gradually from the north coastal waters to the south bay mouth waters, and its isoline formed a series of parallel lines with different grades. Or its isoline formed a series of semi-circle with different grades in eastern off-shore, and its content decreased gradually from the eastern off-shore to outward. The former showed that rain runoff directly input $\mathrm{HCH}$ into the off-shore water area in the bay. The latter showed that the rivers input $\mathrm{HCH}$ into the bay. Therefore, $\mathrm{HCH}$ came from both the area-source and the land.

Under the $\mathrm{HCH}$ prohibition in China in 1983, the $\mathrm{HCH}$ remnant on land decreased largely [9]. The result that the $\mathrm{HCH}$ content into the bay was very low in 1987 was coincident with that [8-11] in 1983, 1984, 1985, and 1986.

From 1979 to 1984 , the HCH content change in Jiaozhou bay coastal waters proved the transfer process of $\mathrm{HCH}$ on land [5-9]: the $\mathrm{HCH}$ content into off-shore changed with rain runoff, namely the change of the $\mathrm{HCH}$ content into the bay with the rainfall. Moreover, in Jiaozhou bay waters, the $\mathrm{HCH}$ content has seasonal change. However, from 1985 to 1987, in the whole Jiaozhou bay waters, the $\mathrm{HCH}$ content was lower than $0.100 \mu \mathrm{g} / \mathrm{L}$ in the whole year, which unveiled that there was no seasonal change in the $\mathrm{HCH}$ content. So, the result represented that with the $\mathrm{HCH}$ remnant decreasing rapidly, the $\mathrm{HCH}$ content in the Jiaozhou bay waters also decreased yearly gradually. Thus, around the Jiaozhou bay, the change of the rainfall, runoff and rivers had no important effect on the change of the $\mathrm{HCH}$ content in the Jiaozhou bay waters.

\subsection{Waters Transfer}

In the Jiaozhou bay waters, in May, July and November, the $\mathrm{HCH}$ contents in surface and bottom is very close, whose result was the same as the result obtained by the analysis of the HCH data of 1979-1986 (the absence of 1980) [5-11].

In May, July and November, in the bay mouth waters, the horizontal distribution and variable trend of the $\mathrm{HCH}$ content between in the surface and the corresponding bottom were inconsistent(Figures 2-7), whose result was consistent with that of the data analysis of 1986, and inconsistent with that of 1979-1986 (the absence of 1980).

Therefore, During the transfer process of the $\mathrm{HCH}$ waters $[6,7]$ put forward by the authors, when the $\mathrm{HCH}$ content was lower than $0.100 \mu \mathrm{g} / \mathrm{L}$, kept down was only the result that the $\mathrm{HCH}$ contents in the surface and bottom were very close. Otherwise, vanished was the result that the horizontal distribution and variable trend of the $\mathrm{HCH}$ content between in the surface and the corresponding bottom were consistent.

\subsection{Input Quantity}

Regarding the whole Jiaozhou bay waters as one water body, $\mathrm{HCH}$ is directly input into the Jiaozhou bay water body from rivers and runoff or open sea outside the bay, considered was the input quantity of $\mathrm{HCH}$ into the Jiaozhou bay water body during one year.

The change of the $\mathrm{HCH}$ content into the bay water body showed the influence of the $\mathrm{HCH}$ prohibition since 1983 in China on the bay water body. Comparing the change of the input quantity into the bay water body in 1979 (four years before the prohibition), 1983(the year of the prohibition) and 1987 (four years after the prohibition), we would illuminate the function of the $\mathrm{HCH}$ prohibition of 1983.

In the whole Jiaozhou bay waters, the input quantity of $\mathrm{HCH}$ in the bay water body in one year was:

Input quantity $=$ the highest $\mathrm{HCH}$ content - the lowest $\mathrm{HCH}$ content

By the calculation above, we would obtain the $\mathrm{HCH}$ input quantities into water body in 1983, 1979 and 1987 (Table 2).

The input quantities made out that the prohibition of $\mathrm{HCH}$ played an important role. In 1979, the $\mathrm{HCH}$ input quantity into the Jiaozhou bay water body reached $12.250 \mu \mathrm{g} / \mathrm{L}$, explaining that farmers used a large amount of pesticide containing $\mathrm{HCH}$, that $\mathrm{HCH}$ passed the transfer process on land [6-11], and that the large amount of $\mathrm{HCH}$ was input into the water body from the rivers. In 1983, namely the year of the $\mathrm{HCH}$ prohibition, the $\mathrm{HCH}$ 
Table 2. Change of $\mathrm{HCH}$ input quantity into the bay before and after the prohibition.

\begin{tabular}{cccc}
\hline Time & 1979 & 1983 & 1987 \\
\hline The Content of $\mathrm{HCH}$ in sea water $/ \mu \mathrm{g} \cdot \mathrm{L}^{-1}$ & $0.230-12.480$ & $0.134-0.768$ & $0.0121-0.0901$ \\
Input quantity $/ \mu \mathrm{g} \cdot \mathrm{L}^{-1}$ & 12.250 & 0.634 & 0.0780 \\
\hline
\end{tabular}

input quantity into the Jiaozhou bay water body reached $0.634 \mu \mathrm{g} / \mathrm{L}$, explaining that farmers could not use the pesticide containing $\mathrm{HCH}$ in farmland, and that the remnant $\mathrm{HCH}$ in soil was input into the water body by runoff. Moreover, the $\mathrm{HCH}$ content inputting into the water body was very low and dropped a level when compared with that before four years. In 1987, the HCH input quantity into the Jiaozhou bay water body reached $0.0780 \mu \mathrm{g} / \mathrm{L}$, explaining that for four years farmers has not used pesticide with $\mathrm{HCH}$ not only in farmland, the remnant $\mathrm{HCH}$ but also in soil was eroded and brought away by runoff, leading to the remnant $\mathrm{HCH}$ on land descending rapidly, and making the $\mathrm{HCH}$ content into the bay water body very low. Compared with that before four years, the $\mathrm{HCH}$ input quantity dropped a level, too.

Therefore, the achievement of the $\mathrm{HCH}$ prohibition in China since 1983 was prominent. By four years before the prohibition, the $\mathrm{HCH}$ was severe pollution. By four years after the prohibition, the $\mathrm{HCH}$ remnant on land sharply declined and the $\mathrm{HCH}$ in waters rapidly reduced. The process from the four years before the $\mathrm{HCH}$ prohibition to the four years after it revealed that by the four years before the $\mathrm{HCH}$ prohibition, the $\mathrm{HCH}$ pollution that human being had brought to the earth was vast distribution and severe harm, the earth from land to rivers and to ocean was gravely polluted by $\mathrm{HCH}$; and that by the four years after the HCH prohibition, the earth promptly eliminated the $\mathrm{HCH}$ pollution that human being had produced, moreover, by the processes of land and waters transfers [6-11], HCH dropped to the sea bottom so that its content on land and in waters was very low.

During the short 8 years, the $\mathrm{HCH}$ content declined two levels of amount, which determined that the ability of the earth for restoring the environmental pollution was greatly powerful.

\section{Conclusions}

According to the data from the investigation in Jiaozhou bay waters in May, July and November in 1987, the distribution, source and seasonal variation of $\mathrm{HCH}$ in Jiaozhou Bay are analyzed. The results showed below:

1) In May, July and November, the $\mathrm{HCH}$ content was less than $0.100 \mu \mathrm{g} / \mathrm{L}$ in the whole year and very low in Jiaozhou bay waters. The HCH content in Jiaozhou bay waters was superior to the Category I, and in addition, the seawater quality in $\mathrm{HCH}$ was much cleaner. When the $\mathrm{HCH}$ content was lower than $0.100 \mu \mathrm{g} / \mathrm{L}$ [11], be- cause of the very low $\mathrm{HCH}$ content and the ocean uniformity [10], there was no seasonal change in $\mathrm{HCH}$ in the bay waters. Certainly, the $\mathrm{HCH}$ content in Jiaozhou bay waters almost was not influenced by the rainfall, runoff and rivers around Jiaozhou bay.

2) In May, July and November, the horizontal distribution of $\mathrm{HCH}$ showed that the $\mathrm{HCH}$ in Jiaozhou bay waters was directly input by runoffs and was input by rivers, and that The $\mathrm{HCH}$ source was area-source and came from land. In May, July and November, the vertical distribution of $\mathrm{HCH}$ showed that the changes of $\mathrm{HCH}$ contents between in surface and the corresponding bottom was inconsistent, and that the horizontal distribution trends of $\mathrm{HCH}$ between in surface and bottom were inconsistent, and that only the $\mathrm{HCH}$ contents in surface and bottom was very close.

3) The change of HCH's input quantity before, in, and after, the forbidden 4 years respectively in 1979, 1983, and 1987, represented the changing process from farmers' using a large amount of pesticide containing $\mathrm{HCH}$ in farmland to the prohibition of using pesticide, and to the fact that for 4 years that pesticide had not been used.

From by four years before the prohibition when the $\mathrm{HCH}$ pollution on land was severe, to by four years after it when the $\mathrm{HCH}$ content in waters was very low, this process revealed that on the one hand, human being's destroying the earth was very terrible; on the other hand, the ability of the earth restoring was also powerful. Surely, the damage of human being had left the trace in nature. The authors considered that when for their own interest, human being would damage the sustainable development of environment and destroy the food chain, human being should profoundly introspect themselves and immediately adopt effective measures, or else it would ruin the earth which human being would exist on. It's very kind that it's never too late to mend

\section{REFERENCES}

[1] G. H. Shi, "A Life of Pesticide," Shanghai Scientific Popular Press, Shanghai, 1992, pp. 85-90.

[2] W. Dou and Z. X. Zhao, "Biologic Concentration of BHC and DDT in Hydrophilous Food Chain in Baiyang Shallow Lake," Environmental Science, Vol. 18, No. 5, 1997, pp. 41-43.

[3] B. X. Mai, Z. Lin and G. Zhang, "The Organic Pollutant Study of the Distribution and Characteristics of Polycyclic Aromatic Hydrocarbons and Organic Chlorine Pes- 
ticides in the Surface of the Sediment in the Zhujiang Estuary and Delta River," Journal of Environmental Science, Vol. 20, No. 2, 2000, pp. 192-197.

[4] T. X. Gu, X. Y. Xu and T. F. Zhang, "Organic Chlorine Pesticide and PCBs in Bohai Bay," Marine Scientific Collected Papers, Vol. 29, 1988, pp. 77-85.

[5] D. F. Yang, Z. H. Gao, H. R. Cao, G. Y. Wen and L. L. Sun, "The Distribution and Transfer of HCH in Jiaozhou Bay," Coastal Engineering, Vol. 27, No. 2, 2008, pp. 6571.

[6] D. F. Yang, Z. H. Gao, P. Y. Sun, L. L. Wang and L. Xie, "The Distribution and Content of $\mathrm{HCH}$ in Spring and Summer in Jiaozhou Bay," Coastal Engineering, Vol. 28, No. 2, 2009, pp. 69-77.

[7] D. F. Yang, Z. H. Gao, H. Huang, J. H. Guo and Y. C. Zhang, "The Distribution and Pollution Source of $\mathrm{HCH}$ in Jiaozhou Bay," Coastal Engineering, Vol. 28, No. 4, 2009, pp. 69-79.

[8] D. F. Yang, Q. Shi, J. H. Guo, W. Tang and Z. R. Ding, "The Distribution and Dilution Process of $\mathrm{HCH}$ in Jiaozhou Bay," Coastal Engineering, Vol. 29, No. 1, 2010, pp. 59-66.

[9] D. F. Yang, J. H. Guo, Z. R. Ding, S. Y. Wu and Q. Shi, "The Distribution and Remnant of $\mathrm{HCH}$ in Jiaozhou
Bay," Coastal Engineering, Vol. 29, No. 2, 2010, pp. 72-76.

[10] D. F. Yang, Z. R. Ding, L. Zheng, Z. G. Bu and Q. Shi, "The Distribution and Uniformity of $\mathrm{HCH}$ in Jiaozhou Bay," Coastal Engineering, Vol. 30, No. 2, 2011, pp. 6674.

[11] D. F. Yang, L. Zheng, H. H. Jiang, Q. Shi and Z. R. Ding, "The Distribution and Water Quality Standard of $\mathrm{HCH}$ in Jiaozhou Bay," Coastal Engineering, Vol. 30, No. 4, 2011, pp. 56-65.

[12] D. F. Yang, F. Wang, Z. H. Gao, W. L. Cui and S. X. Huo, "Ecological Phenomena of Phytoplankton in Jiaozhou Bay," Marine Science, Vol. 28, No. 6, 2004, pp. 71-74.

[13] D. F. Yang, Y. Chen, S. Y. Wu, Z. R. Ding and Q. Shi, "Post-Prohibition Concentrations of $\mathrm{HCH}$ in Jiaozhou Bay I: The Yearly Variation of the $\mathrm{HCH}$ Content," Marine Science, Vol. 34, No. 12, 2010, pp. 52-56.

[14] D. F. Yang, Z. Q. Miao, Z. R. Ding, H. Z. Xu and G. T. Cao, "Post-prohibition concentrations of $\mathrm{HCH}$ in Jiaozhou Bay I: The Variation Process of the HCH Pollution Source," Marine Science, Vol. 35, No. 5, 2011, pp. 112 116. 